\title{
Dominasi dan ketidakadilan negara dan korporasi dalam kasus bencana lumpur Lapindo
}

\author{
Domination and injustice of state and corporate \\ in the case of Lapindo mudflow disaster
}

\author{
Oman Sukmana \\ Program Studi Ilmu Kesejahteraan Sosial, Fakultas Ilmu Sosial dan Ilmu Politik, \\ Universitas Muhammadiyah Malang \\ Jalan Raya Tlogomas No. 246 Malang, Jawa Timur; Telepon (0341)-464318 \\ E-mail: osukmana@ymail.com; Hp/Wa: 082244333075
}

\begin{abstract}
The domination of the state (government) and Corporate (PT LBI) in the oil and gas resource management lead Lapindo mudflow disaster that caused misery to the people. This study aims to assess the forms of domination and injustice by the state (government) and the corporation in the case of Lapindo mudflow disaster, and how Lapindo mudflow disaster victims negotiate (resist) against the state (government) and corporations in an effort to fight for their rights. This study used a qualitative approach with case study. Subjects and informants research include: (1) Lapindo mudflow disaster victims; (2) group coordinator of Lapindo mudflow disaster victims; (3) Public figures Siring village, Tanggulangin, Renokenongo, Jabon, and Jatirejo, Porong district, Sidoarjo; (4) Representation of the corporation (PT. LBI); and (5) Representation of BPLS. The data collection process using the in-deepth interviews, observation, focus group discussions, and review documents. Stage processing and data analysis includes the coding process, memoing, and concept mapping. The results showed that the government (the state) and the corporation (PT LBI) action dominating the oil and gas resource management in the area of Porong district, Sidoarjo regency, East Java, resulting misery for the victims (people). Forms of injustice felt by residents Lapindo mudflow disaster victims not only related to the issue of compensation for land and building assets alone, but more than that, including various dimensions. Through a variety of collective action, such as demonstrations and negotiations, Lapindo mudflow disaster victims filed various charges, such as demands for payment of compensation for land and building assets destroyed.
\end{abstract}

Keywords: domination, injustice, disaster

\begin{abstract}
Abstrak
Dominasi negara (pemerintah) dan Korporasi (PT LBI) dalam pengelolaan sumberdaya Migas mengakibatkan terjadinya bencana Lumpur Lapindo yang berdampak pada munculnya kesengsaraan pada masyarakat. Penelitian ini bertujuan untuk mengkaji bagaimana bentuk dominasi dan ketidakadilan yang dilakukan oleh negara (pemerintah) dan korporasi (PT LBI) dalam kasus bencana Lumpur Lapindo, serta bagaimana korban bencana Lumpur Lapindo melakukan upaya negosiasi (perlawanan) terhadap negara (pemerintah) dan korporasi (PT LBI) dalam upaya memperjuangkan hak-hak mereka. Penelitian ini menggunakan pendekatan kualitatif dengan jenis penelitian studi kasus. Subjek dan Informan penelitian meliputi: (1) masyarakat korban bencana Lumpur Lapindo; (2) koordinator kelompok korban bencana Lumpur Lapindo; (3) Tokoh masyarakat Desa Siring, Tanggulangin, Renokenongo, Jabon, dan Jatirejo, Kecamatan Porong, Sidoarjo; (4) Representai PT. LBI; dan (5) Representasi BPLS. Proses pengumpulan data menggunakan In-deepth Interview, observation, FGD, dan telaah dokumen. Tahap proses pengolahan dan analisis data meliputi proses coding, memoing, dan concept mapping. Hasil penelitian menunjukkan bahwa pemerintah (negara) dan pihak korporasi (PT LBI) melakukan tindakan dominatif dalam pengelolaan sumberdaya Migas di wilayah Kecamatan Porong, Kabupaten Sidoarjo, Jawa Timur, yang mengakibatkan munculnya kesengsaraan bagi korban bencana (masyarakat). Bentuk ketidakadilan yang dirasakan oleh warga korban bencana Lumpur Lapindo bukan hanya terkait dengan persoalan ganti rugi atas aset tanah dan bangunan saja, melainkan lebih luas dari itu, yakni menyangkut berbagai dimensi. Melalui berbagai aksi kolektif, seperti aksi demonstrasi dan negosiasi, korban bencana Lumpur Lapindo mengajukan berbagai tuntutan, antara lain tuntutan pembayaran ganti rugi atas aset tanah dan bangunan yang hancur.
\end{abstract}

Kata kunci: dominasi, ketidakadilan, bencana 


\section{Pendahuluan}

Terjadinya bencana Lumpur Lapindo di Sidoarjo, Jawa Timur, merupakan dampak dari dominasi negara (pemerintah) yang mengeluarkan kebijakan pemberian ijin kepada pihak korporasi (PT LBI) untuk melakukan aktivitas eksplorasi Migas di wilayah blok Brantas, khususnya di wilayah Kecamatan Porong, Kabupaten Sidoarjo. Aktivitas eksplorasi Migas yang dilakukan oleh PT LBI tersebut, diindikasikan mengandung unsur pelanggaran, seperti pelanggaran atas Rencana Tata Ruang Wilayah (RTRW) Kabupaten Sidoarjo, dan pelanggaran Hak Asasi Manusia (HAM). Negara lebih memihak kepada kepentingan korporasi (PT LBI) daripada kepentingan rakyat.

Menurut Lovett (2001:99-100), dominasi mengacu kepada suatu jenis khusus dari relasi antara orangorang dan kelompok. Dalam dominasi harus terdapat beberapa orang atau kelompok sebagai agen dominasi, harus terdapat orang atau kelompok yang berbeda sebagai subjek dominasi, dan harus terdapat suatu keadaan tertentu antara dua pihak, yakni agen dan subjek, yang bisa digambarkan sebagai situasi dan kondisi dominating. Konsep dominasi dapat dikonstruksi dari tiga elemen, yakni: (1) kondisi kekuasaan yang tidak seimbang (the imbalance of power condition); (2) kondisi ketergantungan (the dependency condition); dan (3) kondisi ketidakhadiran atau ketidakpatuhan atas aturan (the absence of rules condition). Dalam konteks fenomena bencana Lumpur Lapindo, maka agen dominasi adalah negara (pemerintah) dan korporasi (PT LBI), subjek dominasi adalah masyarakat korban bencana Lumpur Lapindo, dan situasi dominating adalah kebijakan pemerintah yang memberikan ijin eksplorasi Migas kepada pihak korporasi (PT LBI).

Konsep tentang dominasi dapat dipahami dari pandangan beberapa tokoh teori kritis, seperti Karl Marx, Max Weber, Herbert Marcuse, dan Jurgen Habermas. Karl Marx mengembangan teori dominasi kelas, Max Weber mengembangkan teori dominasi birokrasi, Herbet Marcuse mengembangkan teori dominasi teknokratis, dan Jurgen Habermas mengembangkan teori dominasi budaya (Suka 2012:4349). Selain tokoh teori kritis tersebut, Scott (1990:198) juga menjelaskan tentang tiga bentuk dominasi, yakni: dominasi material (material domination), dominasi status (status domination), dan dominasi ideologis (ideological domination). Dalam konteks penelitian ini, peneliti pendasarkan analisis dominasi berdasarkan teori dominasi kelas dari Karl Marx.

Marx mengembangkan teorinya tentang dominasi kelas. Menurut Marx negara merupakan ekspresi politik dari struktur kelas yang melekat dalam produksi. Dalam masyarakat ber-kelas seperti masyarakat kapitalis, negara didominasi oleh kaum borjuis, dan oleh sebab itu negara merupakan ekspresi politik dari kelas dominan ini (Patria \& Arief 1999:17-18). Dalam rumusan Marx yang terkenal "negara adalah panitia penyelenggara kepentingan kelas borjuis". Munculnya negara dalam masyarakat kapitalis akibat dari tidak terdamaikannya pertentangan kelas (antara borjuis dan proletar) dalam struktur masyarakat tersebut. Negara juga mengontrol perjuangan sosial dari kepentingan ekonomi yang berbeda, dimana kontrol tersebut dipegang oleh kelas yang kuat secara ekonomi dalam masyarakat. Dengan demikian, negara juga menjadi alat represif dari kelas yang berkuasa (Patria \& Arief 1999:177). Selain menjalankan kekuasaan represif, negara juga menjalankan kekuatan hegemoni yang mampu melanggengkan kekuasaannya, yakni kekuasaan kelas dominan. Maka, hegemoni selalu berhubungan dengan penyusunan kekuatan negara sebagai kelas diktator (Patria \& Arief 1999:18).

Dalam konteks kontemporer akhir-akhir ini, Perkins mengembangkan istilah Korporatokrasi (Perkins 2007: x). Istilah Korporatokrasi belum digunakan secara meluas dan merupakan konsep yang relatif baru. Istilah Korporatokrasi digunakan oleh Perkins untuk menunjukkan bahwa dalam rangka membangun imperium global, maka berbagai Korporasi besar, Bank, dan pemerintahan bergabung menyatukan kekuatan finansial dan politiknya untuk memaksa masyarakat dunia mengikuti kehendak mereka. Menurut Wikipedia, dengan merujuk kepada Perkins, Korporatokrasi dilukiskan sebagai sistem kekuasaan yang dikontrol oleh berbagai korporasi besar, bank-bank internasional dan pemerintahan. Menurut Rais (2008:82), sesungguhnya istilah Korporatokrasi dapat digunakan untuk menunjukkan betapa korporasi atau perusahaan besar memang dalam kenyataannya dapat 
mendikte, bahkan kadang-kadang membeli pemerintahan untuk meloloskan keinginan mereka. Kalau sebuah pemerintahan yang dikuasai oleh kaum aristokrat (bangsawan) disebut aristokrasi, sebuah pemerintahan yang dikendalikan oleh kaum plutokrat (orang kaya) disebut sebagai plutokrasi, dan sebuah pemerintahan yang dikendalikan oleh kaum kleptokrat (maling, preman) disebut sebagai kleptokrasi, maka sebuah pemerintahan yang dikendalikan oleh kaum korporatokrat (pemilik korporasi besar) boleh juga dinamakan Korporatokrasi.

Terdapat tiga pilar kekuasaan yang mengatur kehidupan masyarakat demokratis, yaitu kekuasaan negara (state), korporasi (corporate), dan civil society. Negara memiliki political power (kekuasaan politik), korporasi/pasar memiliki corporate/market power (kekuasaan korporasi/pasar), dan civil society memiliki social power (kekuatan sosial). Relasi antara ketiga pilar kekuasaan tersebut harus berjalan selaras dan seimbang (Damsar 2010:129). Dalam beberapa kasus, seringkali hubungan antara ketiganya berjalan timpang, sehingga yang sering terjadi bukannya sinergisme antara ketiganya melainkan ada elemen yang sangat kuat dan ada elemen yang sangat lemah (Febriasih 2009:17). Dalam kasus bencana Lumpur Lapindo, relasi antara negara (pemerintah) dan korporasi (PT LBI) sangat kuat sehingga kebijakan negara (pemerintah) terkait dengan penanganan bencana Lumpur Lapindo lebih menguntungkan pihak korporasi (PT LBI) daripada pihak rakyat (masyarakat).

Penelitian ini bertujuan untuk mengkaji bagaimana bentuk dominasi dan ketidakadilan yang dilakukan oleh negara (pemerintah) dan korporasi (PT LBI) dalam kasus bencana Lumpur Lapindo, serta bagaimana korban bencana Lumpur Lapindo melakukan upaya negosiasi (perlawanan) terhadap negara (pemerintah) dan korporasi (PT LBI) dalam memperjuangkan hak-hak mereka.

\section{Metode Penelitian}

Pendekatan penelitian yang digunakan adalah pendekatan kualitatif (Denzin \& Lincoln 2009:6; Yin 2011:7-8), dengan jenis penelitian studi kasus (Creswell 2007:73). Menurut Denzin \& Guba (dalam Salim 2001:89-101), studi kasus adalah merupakan salah satu metode dari penelitian dengan pendekatan kualitatif. Lokasi penelitian ditentukan di wilayah yang terkena dampak Lumpur Lapindo, yakni di Kecamatan Porong, Jabon, dan Tanggulangin, Kabupaten Sidoarjo, Provinsi Jawa Timur. Informan penelitian ditentukan secara purposive or judgemental sampling (Babbie 2008:204; Neuman 2007:142), yang meliputi: (1) masyarakat korban bencana Lumpur Lapindo; (2) koorditaor kelompok korban bencana Lumpur Lapindo; (3) Tokoh masyarakat Desa Siring, Tanggulangin, Renokenongo, Jabon, dan Jatirejo, Kecamatan Porong, Sidoarjo; (4) Representai PT. LBI; dan (5) Representasi BPLS. Secara garis besar proses pengumpulan data menggunakan empat teknik pokok yang saling berkaitan dan melengkapi, yaitu in-deepth Interview, observation, focus group discussion (FGD), dan telaah dokumen. Tahap proses pengolahan dan analisis meliputi pross coding, memoing, dan concept mapping (Babbie 2008:421). Untuk pengujian keabsahan data, peneliti memfokuskan pada criteria kredibilitas dan kepastian. Teknik kredibilitas yang digunakan adalah perpanjangan keikutsertaan dan triangulasi data. Sedangkan teknik kepastian menggunakan uraian rinci dan teknik audit kebenaran (Denzim \& Guba 2001:78).

\section{Hasil dan Pembahasan}

\section{Bentuk Dominasi Negara dan Korporasi dalam Kasus Bencana Lumpur Lapindo:}

Dominasi pemerintah (negara) dan pihak PT LBI (korporasi) pengelolaan sumberdaya Migas di wilayah Kecamatan Porong, Kabupaten Sidoarjo, Jawa Timur, mengakibatkan terjadinya bencana Lumpur Lapindo yang berdampak pada munculnya kesengsaraan bagi masyarakat. Gambaran bentuk dominasi pemerintah (negara) dan korporasi (PT LBI) dalam arena peristiwa bencana Lumpur Lapindo, sebagai berikut (Sukmana 2017:262): 
Pertama; Kebijakan pemerintah dalam memberikan ijin eksplorasi Migas kepada pihak PT LBI di wilayah Kecamatan Porong, Kabupaten Sidoarjo melanggar penggunaan peruntukkan Rencana Tata Ruang Wilayah (RTRW) wilayah Kecamatan Porong, Kabupaten Sidoarjo sebagaimana diatur dalam Perda Kabupaten Sidoarjo Nomor 16 tahun 2003 tentang Rencana Tata Ruang Wilayah (RTRW) Kabupaten Sidoarjo tahun 2003-2012, Perda Kabupaten Sidoarjo Nomor 6 Tahun 2009 tentang RTRW Kabupaten Sidoarjo tahun 2009-2029, Perda Provinsi Jawa Timur Nomor 2 Tahun 2006 tentang RTRW Jawa Timur 2005-2020. Selain itu juga melanggar Undang-undang Nomor 26 Tahun 2007 tentang Penataan Ruang, Undang-undang Nomor 23 Tahun 1997 tentang Pengelolaan Lingkungan Hidup, dan PP Nomor 27 Tahun 1999 tentang Analisis Mengenai Dampak Lingkungan.

“..Apabila dicermati dari pasal-pasal yang ada dalam PP Nomor 27 tahun 1999 tentang Analisis Mengenai Dampak Lingkungan tersebut, maka diduga terdapat pelanggaran yang dilakukan oleh PT LBI, sesuai pasal 7 ayat (1) yang menyatakan bahwa "analisis mengenai dampak lingkungan hidup merupakan syarat yang harus dipenuhi untuk mendapatkan ijin melakukan usaha dan atau kegiatan yang diterbitkan oleh pejabat yang berwenang..." (Akbar 2012)

Kedua; Komisi Nasional Hak Asasi Manusia (Komnas HAM) menyatakan kasus bencana lumpur Lapindo yang terjadi di Kabupaten Sidoarjo, Jawa Timur, merupakan pelanggaran terhadap hak asasi manusia. Komite Nasional Hak Asasi Manusia Indonesia, mencatat bahwa bencana Lumpur Lapindo di Sidoarjo telah menimbulkan kondisi yang mengakibatkan tidak terlindungi dan terpenuhinya hak asasi korban. Hak-hak yang terlanggar antara lain: (1) Hak atas pekerjaan dan penghidupan yang layak bagi kemanusiaan, seperti dijamin dalam Pasal 27 Ayat (2) UUD 1945; (2) Hak untuk bekerja, mendapat imbalan, dan perlakuan adil dan layak dalamhubungan kerja, sebagaimana dijamin Pasal 28-D Ayat (2) UUD 1945; (3) Hak untuk hidup serta mempertahankan hidup dan kehidupannya, sebagaimana dijamin Pasal 27-A UUD 1945; (4) Hak atas perlindungan diri pribadi, keluarga, kehormatan, martabat, dan harta benda yang di bawah kekuasaannya, serta hak atas rasa aman dan perlindungan dari ancaman ketakutan untuk berbuat atau tidak berbuat sesuatu, yang merupakan hak asasi, seperti dijamin Pasal 28-G Ayat (1) UUD 1945; (5) Hak untuk hidup sejahtera lahir dan batin, bertempat tinggal, dan mendapat lingkungan hidup yang baik dan sehat, serta hak mendapat layanan kesehatan, sebagaimana dijamin Pasal 28-H Ayat (1) UUD 1945; (6) Hak mengembangkan diri melalui pemenuhan kebutuhan dasar; hak mendapat pendidikan dan manfaat dari ilmu pengetahuan, teknologi, seni, dan budaya, demi meningkatkan kualitas hidup dan demi kesejahteraan manusia, seperti dijamin Pasal 28-C UUD 1945; dan (7) Hak anak atas kelangsungan hidup, tumbuh, dan berkembang, sebagaimana dijamin Pasal 28-B Ayat (2) UUD 1945. Pasal 28-I UUD 1945 mengamanatkan, perlindungan, pemajuan, penegakan, dan pemenuhan hak asasi manusia adalah tanggung jawab negara, terutama pemerintah.

Ketiga; Masyarakat di sekitar Porong, khususnya masyarakat Desa Renokenongo, melihat adanya proses yang tidak transparan dalam proyek eksplorasi Migas yang dilakukan oleh PT LBI. Semula perwakilan dari pihak PT LBI menyampaikan kepada masyarakat bahwa pembelian tanah warga oleh PT LBI akan diperuntukkan bagi pengembangan kawasan peternakan ayam, bukan untuk lokasi pengeboran minyak dan gas (Migas).

Keempat; Bencana semburan Lumpur Lapindo di Sidoarjo menjadi arena produksi kemiskinan dan ketidak berdayaan bagi warga yang ada di wilayah Kecamatan Porong, dan sekitarnya, yang menjadi korban bencana Lumpur Lapindo. Menurut penjelasan beberapa warga, pada umumnya korban bencana Lumpur Lapindo kehidupannya menjadi miskin dan tidak berdaya. Sekitar 15.788 Kepala Keluarga (KK) atau 48.983 jiwa harus pindah meninggalkan wilayah Kecamatan Porong. Tercatat ada 33 perusahaan yang hancur tenggelam Lumpur Lapindo yang mengkibatkan sekitar 10.000 karyawan/buruh terpaksa harus menganggur. 
Kelima; Dominasi pemerintah atas korban bencana Lumpur Lapindo tercermin juga dalam kebijakan pemerintah terkait penyelesaian permasalahan dampak bencana Lumpur Lapindo. Salah satu konsekuensi dari terbitnya payung (jaminan) hukum berupa Peraturan Presiden (Perpres) terkait pembayaran ganti rugi bagi korban bencana Lumpur Lapindo adalah ketentuan yang mengatur relasi antara warga korban bencana Lumpur Lapindo dengan pihak PT LBI dan pemerintah menjadi relasi antara penjual-pembeli (relasi jual-beli), dimana warga korban bencana Lumpur Lapindo diposisikan sebagai penjual dan pihak pemerintah dan PT LBI sebagai pihak pembeli. Warga korban bencana Lumpur Lapindo harus menunjukkan bukti-bukti otentik, seperti sertifikat dan bukti Ijin Mendirikan Bangunan (IMB) agar bisa mendapatkan ganti rugi dari pihak PT LBI dan pemerintah. Bencana semburan Lumpur Lapindo di Sidoarjo tidak hanya memproduksi ketidakadilan, akan tetapi juga menjadi arena produksi kemiskinan dan ketidakaberdayaan bagi warga yang ada di wilayah Kecamatan Porong, dan sekitarnya, yang menjadi korban bencana Lumpur Lapindo.

\title{
Ketidakadilan dalam Kasus Bencana Lumpur Lapindo
}

Dalam konteks bencana lumpur Lapindo, terdapat beberapa hal yang dirasakan oleh warga korban bencana sebagai bentuk ketidakadilan. Bentuk ketidakadilan yang dirasakan oleh warga korban bencana Lumpur Lapindo bukan hanya terkait dengan persoalan ganti rugi atas aset tanah dan bangunan saja, melainkan menyangkut berbagai dimensi. Hal-hal yang dirasakan sebagai bentuk ketidakadilan oleh warga korban bencana Lumpur Lapindo di Sidoarjo, antara lain sebagai berikut: Pertama; terkait dengan persoalan kontroversi tentang masalah perijinan pengeboran. Masyarakat di sekitar Porong, khususnya masyarakat Desa Renokenongo, melihat adanya proses yang tidak transparan dalam proyek pemboran yang dilakukan oleh PT LBI. Semula pihak PT LBI menyampaikan kepada masyarakat bahwa pembelian tanah warga oleh PT LBI diperuntukkan bagi pengembangan kawasan peternakan ayam, bukan untuk lokasi pengeboran minyak dan gas (Migas).

Saat transaksi jual beli, kebanyakan warga tidak mengetahui bahwa sawah mereka akan dibeli oleh PT LBI, karena proses jual-beli diwakili oleh Kepada Desa Renokenongo, yakni Mahmudatul Fatchiyah. Ketika itu para pemilik sawah yang kebanyakan dari warga RT 18, 19, dan 20, Desa Renokenongo tidak mengetahui persis siapa sesungguhnya pihak yang membeli tanah mereka. Warga percaya kepada keterangan Kepala Desa Renokenongo bahwa tanah warga dibeli untuk keperluan peternakan ayam. Setelah transaksi jual beli terjadi, lokasi itu kemudian ditutup dengan seng, hingga warga tidak mengtahui apa yang dikerjakan di dalam pagar. Warga mulai menyadari bahwa lokasi tersebut digunakan untuk pemboran setelah mendengar suara besi dipukul berulang-ulang.

\begin{abstract}
"Iya.. kami melihat memang dari awalnya pembebasan tanah itu sudah tidak transparan, dikatakan bahwa pembelian tanah itu untuk peternakan, apa ini untuk mengelabui masyarakat, apa ini teknis mereka, mestinya menurut saya ya harus transparan saja biar masyarakat juga tahu, apa itu ditolak apa tidak itu kan urusan belakangan, yang penting masyarakat diberi tahu harus transparan... masyarakat juga tiba-tiba tahu kalau itu untuk pengeboran yang mestinya harganya harus mahal, ternyata kalau untuk peternakan kan bisa murah, ini awal dari proses pembelian tanah...dan memang seumpama transparan mungkin masyarakat tidak mau, banyak yang menolak" (Hasil wawancara dengan Snt.)
\end{abstract}

Kedua; Ketidakadilan yang terkait dengan inkonsistensi pelaksanaan kebijakan penggunaan peruntukkan Tata Ruang. Sesuai dengan Peraturan Daerah (Perda) Kabupaten Sidoarjo Nomor 16 Tahun 2003 tentang Rencana Tata Ruang Wilayah (RTRW) Kabupaten Sidoarjo tahun 2003-2012, bahwa peruntukkan wilayah Kecamatan Porong, Tanggulangin dan Jabon diprioritaskan hanya untuk kawasan pemukiman, pertanian dan industri, bukan untuk kawasan eksploitasi minyak dan gas (pertambangan). Kemudian Perda Nomor 16 Tahun 2003 diperbaharui lagi dan terbit Perda Nomor 6 Tahun 2009 tentang RTRW Kabupaten Sidoarjo tahun 2009-2029, dimana dicantumkan bahwa wilayah Kecamatan Porong, Kecamatan Jabon, dan sebagian Kecamatan Tanggulangin, bersama dengan Kecamatan Tulangan, dan Kecamatan Krembung adalah termasuk ke dalam Sub Satuan Wilayah Pengembangan (SSWP) III, dengan fungsi utama sebagai kawasan permukiman, konservasi geologi, industri, pertanian, dan perdagangan skala regional dengan pusat pertumbuhan berada di 
kawasan Krembung. Sejalan dengan Perda Kabupaten Sidoarjo Nomor 16 tahun 2003, Pemerintah Provinsi Jawa Timur mengeluarkan Peraturan Daerah (Perda) Provinsi Jawa Timur Nomor 2 Tahun 2006 tentang RTRW Jawa Timur 2005-2020 yang juga menyatakan antara lain bahwa kawasan Sidoarjo, khususnya wilayah Kecamatan Porong diperuntukkan bagi kawasan pemukiman, pertanian, dan industri.

PT LBI dan Pemerintah Daerah Kabupaten Sidoarjo, juga telah melakukan pelanggaran terhadap pasal 3 dan 37 Undang-undang Nomor 26 Tahun 2007 tentang Penataan Ruang. Mengacu kepada Pasal 3, disebutkan bahwa penyelenggaraan penataan ruang bertujuan untuk mewujudkan ruang yang aman, nyaman, produktif, dan berkelanjutan berlandaskan Wawasan Nusantara dan Ketahanan Nasional, dengan: (a) terwujudnya keharmonisan antara lingkungan alam dan lingkungan buatan; (b) terwujudnya keterpaduan dalam penggunaan sumber daya alam dan sumber daya buatan dengan memperhatikan sumber daya manusia; dan (c) terwujudnya pelindungan fungsi ruang dan pencegahan dampak negatif terhadap lingkungan akibat pemanfaatan ruang. Sementara apabila mengacu kepada pasal 37 Undang-undang Nomor 26 Tahun 2007 dinyatakan bahwa antara lain: (a) Ijin pemanfaatan ruang yang tidak sesuai dengan rencana tata ruang wilayah dibatalkan oleh pemerintah dan pemerintah daerah menurut kewenangan masing-masing sesuai dengan ketentuan peraturan perundangundangan; (b) Ijin pemanfaatan ruang yang dikeluarkan dan/atau diperoleh dengan tidak melalui prosedur yang benar, batal demi hukum; (c) Ijin pemanfaatan ruang yang diperoleh melalui prosedur yang benar tetapi kemudian terbukti tidak sesuai dengan rencana tata ruang wilayah, dibatalkan oleh pemerintah dan pemerintah daerah sesuai dengan kewenangannya; (d) Ijin pemanfaatan ruang yang tidak sesuai lagi akibat adanya perubahan rencana tata ruang wilayah dapat dibatalkan oleh pemerintah dan pemerintah daerah dengan memberikan ganti kerugian yang layak; dan (e) Setiap pejabat pemerintah yang berwenang menerbitkan izin pemanfaatan ruang dilarang menerbitkan ijin yang tidak sesuai dengan rencana tata ruang. Dalam konteks lumpur Lapindo, pemerintah daerah bukannya kemudian mencabut ijin pemanfaatan ruang yang tidak sesuai dengan Rencana Umum Tata Ruang (RUTR) Kabupaten Sidoarjo, tetapi malahan membiarkan dan bahkan mendukungnya.

\begin{abstract}
"Iyaa... apapun itu entahlah itu Lapindo ataupun pihak terkait dalam hal ini.. mesti corporate ini punya ijin, ijin nya dari mana? Ya pemerintah saat itu, berarti berurusan sama.. karena ini dipake tambang berarti urusannya dengan pemerintah yang menangani masalah tambang... padahal kalau menurut aturan penambangan kan tidak boleh di wilayah atau di pertengahan perkampungan pemukiman, ini tidak hanya...bukan hanya ngomong satu kilo tapi meter dari pemukiman warga.. ini sudah merupakan kejahatan besar...pelanggaran besar..ini harus dicatat bahwa ini pelanggaran maka itu pasti yang bertanggung jawab dua hal, yaitu corporate itu sendiri karena melakukan pengeboran di tengah warga; yang kedua pemerintah masalah ijin, kenapa ijin itu bisa ke luar di wilayah pemukiman,padaha kawasan Kecamatan Porong itu adalah bukan untuk kawasan pengeboran migas" (Hasil wawancara dengan Msk).
\end{abstract}

Ketiga; Bentuk ketidakadilan yang dirasakan oleh warga korban lumpur lapindo yang terkait dengan faktor penyebab terjadinya semburan lumpur. Warga korban menyatakan bahwa faktor penyebab terjadinya bencana semburan lumpur panas di wilayah Porong dan sekitarnya adalah karena faktor kesalahan manusia (nonalam). Mengacu kepada UU No. 24 Tahun 2007 tentang Penanggulangan Bencana, disebutkan bahwa bencana meliputi bencana alam, bencana nonalam, dan bencana sosial. Bencana alam adalah bencana yang diakibatkan oleh peristiwa atau serangkaian peristiwa yang disebabkan oleh alam antara lain berupa gempa bumi, gunung meletus, banjir, kekeringan, angin topan, dan tanah longsong. Bencana nonalam adalah bencana yang diakibatkan oleh peristiwa atau serangkaian peristiwa nonalam yang antara lain berupa gagal teknologi, gagal modernisasi, dan wabah penyakit. Sementara bencana sosial adalah bencana yang diakibatkan oleh peristiwa atau serangkaian peristiwa yang diakibatkan oleh manusia yang meliputi konflik sosial antar kelompok atau antar komunitas masyarakat. Menurut Akbar (2012:123), semburan lumpur panas yang terjadi di Desa Siring, Kecamatan Porong, Sidoarjo, pada tanggal 29 Mei 2009 diduga akibat kegiatan eksplorasi pertambangan minyak dan gas bumi sumur Banjar Panji-1 di blok Brantas yang dioperatori oleh PT LBI. Dugaan kelalaian prosedur dalam kegiatan tersebut telah mengakibatkan terjadinya pencemaran dan perusakan lingkungan hidup yang dapat dikategorikan sebagai bencana nonalam. 
Pihak pemerintah dan pihak PT LBI menyatakan bahwa faktor penyebab terjadinya bencana semburan lumpur panas tersebut adalah karena faktor alam. Berdasarkan putusan Pengadilan Negeri Jakarta Pusat 27 November 2007, yang isinya menolak gugatan Yayasan Lembaga Bantuan Hukum Indonesia (YLBHI), menyatakan bahwa pemerintah dan PT LBI tidak terbukti melakukan perbuatan melawan hukum. Putusan Pengadilan Tinggi (PT) Jakarta pada tanggal 13 Juni 2008, yang isinya menguatkan putusan Pengadilan Negeri (PN) Jakarta Pusat tanggal 27 Nopember 2007, bahwa adanya kejadian semburan lumpur di Sidoarjo karena kecenderungan gejala alam lebih dominan, bukan sebagai kesalahan manusia. Putusan Kasasi Mahkamah Agung (MA), tanggal 3 April 2009, yang isinya menolak permohonan Kasasi YLBHI, menyatakan bahwa semburan lumpur di Sidoarjo merupakan fenomena alam dan bukan kesalahan industri dan putusan ini mempunyai kekuatan hukum tetap (inkracht).

Keempat; Bentuk ketidakadilan yang dirasakan oleh warga korban bencana Lumpur Lapindo terkait dengan penyebutan istilah. Warga masyarakat menyebutnya dengan istilah bencana Lumpur Lapindo (Lula), sementara pihak pemerintah dan PT LBI menyebutnya dengan istilah bencana Lumpur Sidoarjo (Lusi). Masyarakat korban bencana semburan lumpur menyebut bencana Lumpur Lapindo karena menganggap bahwa sumber dari terjadinya bencana semburan lumpur tersebut adalah karena ulah dari PT. LBI yang melakukan eksplorasi Migas. Istilah Lumpur Sidoarjo menunjukkan kesan bahwa pihak PT LBI tidak bersalah atas terjadinya bencana semburan lumpur yang menyebabkan penderitaan bagi warga masyarakat di Kecamatan Porong dan sekitarnya.
“...Sebenarnya orang sudah secara apa ya..secara umum orang sudah menyebut, karena perusahaan yang mengeksplorasinya adalah perusahaan Lapindo Brantas, orang lebih familiar mengatakan ini lumpur lapindo, sebenarnya itu secara tidak langsung lumpur yang diciptakan yang diakibatkan oleh eksplorasi PT. Lapindo Brantas, dan Pemerintah rupanya lebih mengarahkan, lebih bias lagi menjadi lumpur Sidoarjo supaya ini.....tidak terfokus pada perusahaan Lapindo-nya....Betul, konsekuensi tanggung jawab, sebab tidak hanya tanggung jawab moral tapi sosial juga, karena memang ini adalah penanganan yang memang semestinya lapindo itu adalah yang paling bertanggung jawab setiap permasalahan sebelum di take over atau di anu oleh pemerintah..." (Kutipan wawancara dengan AJ).

Kelima; Bentuk ketidakadilan yang dirasakan warga korban bencana Lumpur Lapindo di Sidoarjo, khususnya warga korban yang ada di sekitar pusat semburan Lumpur Lapindo, yang wilayahnya masuk ke dalam Peta Area Terdampak (Dalam PAT), yakni yang ada di wilayah Desa Renokenongo, Siring, Glagaharum, Jatierjo (Kecamatan Porong), Desa Kedungbendo, Ketapang, Gempolsari, Kalitengah (Kecamatan Tanggulangin), dan Kalitengah, Pejarakan, dan Desa Keboguyang (Kecamatan Jabon), adalah berkaitan dengan pembagian tanggungjawab proses pembayaran ganti rugi. Sebagaimana diatur dalam Perpres Nomor 14 Tahun 2007, disebutkan bahwa warga korban yang masuk ke wilayah Dalam PAT maka proses penyelesaian ganti ruginya menjadi tanggungjawab PT. LBI, sementara warga korban di wilayah Luar PAT proses penyelesaian ganti ruginya menjadi tanggungjawab pemerintah melalui dana Anggaran Pendapatan dan Belanja Negara (APBN). Dalam perjalanan selanjutnya, proses ganti rugi di wilayah Dalam PAT tidak berjalan dengan lancar, bahkan hingga tahun 2012 PT. LBI belum menyelesaikan proses ganti rugi secara tuntas. Sementara bagi warga korban yang ada di wilayah Luar PAT, yang proses ganti ruginya menjadi tanggungjawab pemerintah melalui dana APBN, pelaksanaan pembayaran ganti rugi relatif berjalan dengan lancar. Kondisi ini dianggap oleh warga korban yang masuk ke wilayah Dalam PAT sebagai bentuk diskriminasi dan ketidakadilan dari pemerintah terhadap warga negara.

Keenam; Bentuk ketidakadilan yang dirasakan oleh warga korban bencana Lumpur Lapindo yang terkait dengan perlakuan terhadap warga yang terkena dampak semburan lumpur, yakni bahwa mereka menjadi masyarakat korban bencana alam. Sebagai korban bencana alam, warga terpaksa harus pindah meninggalkan tempat tinggalnya dengan hanya mendapatkan bantuan uang jatah hidup selama tiga bulan. Sementara pembayaran ganti rugi atas tanah dan bangunan yang hancur dan hakhak lainnya tidak mendapatkan jaminan.

Ketujuh; Bentuk ketidakadilan yang dirasakan oleh warga korban lumpur lapindo yang terkait peran 
pemerintah yang lebih pro-kapitalis (pro-pengusaha) daripada pro-rakyat (warga korban). Sikap pemerintah dianggap "lunak" terhadap pihak PT LBI. Sukiadi (dalam Akbar, 2012:xxiv) menyatakan bahwa kasus Lumpur Lapindo adalah praktek kasat mata Korporatokrasi sebagai akibat rusaknya sistem ketatanegaraan sehingga negara harus menanggung kejahatan korporasi melalui APBN, yang berujung pada merosotnya kemampuan negara dalam memberikan kesejahteraan rakyat banyak. Korporatokrasi adalah sistem kekuasaan yang dikontrol oleh berbagai korporasi besar, bank-bank internasional, dan pemerintahan. Istilah Korporatokrasi dapat digunakan untuk menunjukkan betapa korporasi atau perusahaan besar memang dalam kenyataannya dapat mendikte, bahkan kadangkadang membeli pemerintahan untuk meloloskan keinginan mereka. Kalau sebuah pemerintahan yang dikuasai oleh kaum aristokrat (bangsawan) disebut aristokrasi, sebuah pemerintahan yang dikendalikan oleh kaum plutokrat (orang kaya) disebut sebagai plutokrasi, dan sebuah pemerintahan yang dikendalikan oleh kaum kleptokrat (maling, preman) disebut sebagai kleptokrasi, maka sebuah pemerintahan yang dikendalikan oleh kaum korporatokrat (pemilik korporasi besar) boleh juga dinamakan Korporatokrasi (Rais 2008: 82).

Kedelapan; Bentuk ketidakadilan terkait dengan peran pihak PT LBI dalam proses penyelesaian masalah dampak semburan lumpur. Abu rizal Bakrie mengaku tidak merasa bersalah atas terjadinya bencana semburan Lumpur Lapindo Sidoarjo. Meski begitu, pihaknya tetap memberikan ganti rugi dengan cara membeli tanah dan bangunan warga lantaran "titah ibundanya". Menurut Aburizal Bakrie, pihak PT LBI sudah dinyatakan tidak bersalah oleh pihak MA, dengan demikian keputusannya sudah berkekuatan hukum tetap. Hanya saja, karena "sang ibu" memerintahkan Aburizal Bakrie untuk membeli tanah dan bangunan, maka dia mengaku mematuhinya. Aburizal Bakrie menjelaskan tanah dan bangunan milik warga itu itu bukan ganti rugi, melainkan melalui proses jual beli dengan harga Nilai Jual Objek Pajak (NJOP) yang seharusnya sebesar Rp 60.000 per meter persegi, tetapi dihargai oleh PT LBI sebesar Rp 1 juta.

\section{Negosiasi Kolektif Korban Bencana Lumpur Lapindo terhadap Negara dan Korporasi}

Sukmana (2017) menjelaskan melalui berbagai aksi kolektif, seperti aksi demonstrasi dan negosiasi, korban bencana Lumpur Lapindo menyampaikan beberapa tuntutan. Proses negosiasi kolektif yang dilakukan oleh korban bencana Lumpur Lapindo terhadap pihak pemerintah dan PT. LBI, meliputi:

Pertama; proses negosiasi kolektif korban bencana Lumpur Lapindo terkait nilai ganti rugi. Korban bencana Lumpur Lapindo harus menerima kenyataan bahwa secara hukum pihak pemerintah (negara) dan pihak korporasi (PT LBI) dinyatakan sebagai pihak yang tidak bersalah atas terjadinya bencana semburan Lumpur Lapindo di Sidoarjo. Warga korban bencana Lumpur Lapindo juga harus bisa menerima "nasib" bahwa mereka adalah korban bencana alam. Namun demikian warga korban bencana Lumpur Lapindo ternyata tidak menerima begitu saja bahwa mereka sebagai korban bencana alam. Korban bencana Lumpur Lapindo berusaha membangun kekuatan kolektif untuk mengajukan tuntutan ganti rugi atas aset tanah dan bangunan milik mereka yang hancur tergenang lumpur, melalui upaya penjaringan aspirasi.

Selanjutnya, beberapa perwakilan korban bencana Lumpur Lapindo dari Desa Jatirejo mengajukan tuntutan untuk mendapatkan ganti rugi kepada Tim Nasional Penanggulangan Semburan Lumpur Sidoarjo (TimNas PSLS) dan PT. LBI. Berdasarkan kesepakatan warga, kemudian disampaikan tuntutan nilai pembayaran ganti rugi untuk tanah darat sebesar $\mathrm{Rp} 2$ juta dan untuk bangunan sebesar Rp. 2,5 juta per-meter persegi. Namun PT LBI melakukan penawaran harga menjadi sebesar Rp. 500 ribu untuk tanah dan sebesar Rp. 750 ribu untuk bangunan per-meter perseginya.

Penawaran dari pihak PT. LBI ini kemudian mendapat penolakan dari warga korban bencana Lumpur Lapindo. Khoirul Huda dan beberapa perwakilan warga kemudian melakukan bargaining (negosiasi) dan tekanan kepada pihak PT. LBI. Bahkan warga korban bencana Lumpur Lapindo mengancam akan melakukan aksi demonstrasi yang menurunkan ribuan warga korban bencana. Menghadapi tekanan warga korban bencana Lumpur Lapindo, akhirnya PT. LBI menaikkan tawaran nilai ganti 
rugi menjadi sebesar Rp. 1 juta untuk tanah darat dan Rp. 1,5 juta untuk bangunan per meter persegi. Usulan PT. LBI ini kemudian bisa diterima oleh warga korban lumpur Lapindo, yakni sebesar 92\% warga korban bencana Lumpur Lapindo menerimanya. Sementara nilai penggantian untuk tanah sawah diputuskan sebesar Rp. 125 ribu per-meter persegi yang mengacu kepada hasil kesepakatan antara warga Desa Mindi dengan PT. LBI yang telah terlebih dahulu diputuskan. Kesepakatan harga ganti rugi ini, yakni: sebesar Rp. 1 juta untuk tanah darat, Rp. 1,5 juta untuk bangunan, dan Rp. 125 ribu untuk tanah sawah per meter persegi, kemudian berlaku untuk semua wilayah yang terkena dampak lumpur Lapindo, baik wilayah di dalam Peta Area Terdampak maupun wilayah di luar Peta Area Terdampak.

Upaya negosiasi kolektif yang dilakukan korban bencana Lumpur Lapindo, khususnya terhadap pihak korporasi (PT LBI), dalam menuntut besaran nilai ganti rugi atas aset tanah dan bangunan milik mereka yang hancur tenggelam luapan lumpur ternyata mengalami keberhasilan.

Kedua; proses negosiasi kolektif terkait jaminan (payung) hukum bagi korban bencana Lumpur Lapindo. Proses negosiasi kolektif korban bencana Lumpur Lapindo ternyata tidak hanya berhenti sampai perjuangan untuk mencapai kesepakatan besaran nilai ganti rugi saja. Karena, setelah besaran nilai ganti rugi disepakati oleh warga korban bencana Lumpur Lapindo dan pihak PT LBI, muncul persoalan berikutnya yakni berkaitan dengan belum adanya payung hukum yang dapat menjamin terlaksananya kesepakatan terkait besaran nilai ganti rugi ini. Warga korban lumpur Lapindo kemudian mendesak kepada pihak pemerintah melalui Tim Nasional Penanggulangan Semburan Lumpur Sidoarjo (TimNas PSLS) dan PT LBI untuk segera dikeluarkan payung hukum yang dapat menjamin pelaksanaan pembayaran ganti rugi yang nilai pembayarannya sudah disepakati oleh pihak PT LBI dan warga korban tersebut.

Atas tuntutan warga korban bencana Lumpur Lapindo tersebut, selanjutnya dalam memberikan payung hukum kepada warga korban Lumpur Lapindo pihak pemerintah menerbitkan Peraturan Presiden (Perpres) Nomor 14 Tahun 2007 tertanggal 8 April 2007 tentang BPLS sebagai revisi atas Keputusan Presiden (Kepres) Nomor 13 Tahun 2006.

Ketiga; proses negosiasi kolektif terkait alat bukti kepemilikan aset. Salah satu konsekuensi dari terbitnya payung hukum berupa Peraturan Presiden (Perpres) Nomor 14 Tahun 2007, terkait pembayaran ganti rugi bagi korban bencana Lumpur Lapindo adalah ketentuan yang mengatur relasi antara warga korban bencana Lumpur Lapindo dengan pihak PT. LBI dan pemerintah menjadi relasi antara penjual-pembeli (relasi jual-beli). Artinya pihak warga korban bencana dianggap sebagai pihak penjual aset tanah dan bangunan, sementara pihakk PT. LBI dan Pemerintah diposisikan sebagai pihak pembeli. Dalam pasal 15 (1) Peraturan Presiden (Perpres) Nomor 14 Tahun 2007 dijelaskan bahwa: "Dalam rangka penanganan masalah sosial kemasyarakatan, PT. Lapindo Brantas membeli tanah dan bangunan masyarakat yang terkena luapan lumpur Sidoarjo dengan pembayaran secara bertahap, sesuai dengan peta area terdampak tanggal 22 Maret 2007 dengan akta jual-beli bukti kepemilikan tanah yang mencantumkan luas tanah dan lokasi yang disahkan oleh Pemerintah".

Proses jual-beli ini harus dilakukan dengan menggunakan akad jual-beli di hadapan notaris. Persoalan berikutnya yang muncul adalah berkaitan dengan persyaratan administratif sebagai bukti yang sah atas kepemilikan aset warga. Pihak PT LBI dan Pemerintah meminta persyaratan bukti berupa sertifikat untuk tanah dan surat Ijin Mendirikan Bangunan (IMB) untuk bangunan, sementara bukti letter-C dan petok-D tidak diakui sebagai bukti yang sah.

Persoalan yang muncul adalah bahwa ternyata bukti persyaratan administratif yang disyaratkan oleh pihak PT LBI tidak bisa dipenuhi oleh warga korban bencana Lumpur Lapindo karena sebagai besar dari mereka tidak memiliki bukti sertifikat dan IMB. Misalnya, dari 800 berkas yang milik warga korban bencana Lumpur Lapindo yang berasal dari Desa Jatirejo, hanya 10 orang yang memiliki sertifikat tanah dan hanya satu orang yang memiliki IMB. Sementara dari jumlah keseluruhan berkas milik warga korban bencana Lumpur Lapindo dari empat desa, yakni sebanyak 4.000 berkas, dimana 
yang paling banyak berkas milik warga dari Desa Kedungbendo, ternyata hanya 110 berkas saja yang bersertifikat. Atas kondisi ini kemudian warga korban melakukan perlawanan dan menolak persyaratan administrasi yang ditetapkan pihak PT LBI. Setelah melalui negosiasi kolektif yang cukup alot maka pada akhirnya PT LBI menyepakati untuk mengakui bukti petok-D dan letter-C diakui sebagai bukti yang sah.

Setelah petok D dan letter C diakui sebagai bukti sah sebagai pengganti sertifikat tanah, baik tanah sawah maupun tanah darat, kemudian muncul problem berikutnya yakni terkait dengan bukti IMB untuk tanah bangunan yang masih belum klir. Untuk mengatasi masalah ini kemudian Cak Nun (Emha Ainun Nadjib) mengusulkan model mekanisme "sumpah". Artinya warga korban satu-persatu diminta menjelaskan posisi dan luas tanah-bangunannya kemudian mereka disumpah. Pengambilan sumpah dilakukan di Pendopo Kabupaten Sidoarjo di hadapan Bupati, Can Nun, pihak PT LBI, disaksikan oleh Rukun Tetangga (RT), Rukun Warga (RW), tetangga, kemudian di setempel desa dan kecamatan.

\begin{abstract}
“...Tapi memang ada permasalahan administratif. Satu, permasalahan administratif itu ternyata, apa namanya, a..Lapindo waktu itu menghendaki tanah yang akan dibeli itu adalah tanah Sertifikat, bukan petok D atau letter C. Yang kedua, yang disebut bangunan adalah dibuktikan dengan IMB, satu-satunya bukti bangunan itu adalah IMB. Nah, kami waktu itu harus membikin Perlawanan, karena apa? Karena dari warga Jatirejo yang berkasnya hampir 800 berkas, bukan jiwa pak, berkas itu yang pemilik tanahnya. Satu orang bisa saja memiliki dua berkas, atau satu berkas bisa saja milik dari 4 orang, misalnya tanah warisan. Nah itu hampir 800 berkas itu hanya 10 orang yang punya sertifikat. Jatirejo saja. Terus kemudian dari 4000 berkas dari empat desa, yang paling banyak itu di desa Kedungbendo. Jadi dari 4000 berkas yang ada di empat desa itu, jadi kita sudah berserkat tapi belum ada nama, itu hanya 110 saja berkas yang bersertifikat. Artinya yang lain petok D atau letter C. Nah itu sertifikat. Terus yang kedua, masalah bangunan. Di Jatirejo itu dari 800 berkas hanya satu orang yang punya IMB, yang lain tidak punya. Ini kebetulan yang punya IMB itu dulu pegawai pajak atau pegawai apa gitu, mungkin sudah melek administrasi dia punya IMB. Yang lain tidak punya. Ini yang menjadi perlawanan kami, kami merasa bahwasanya ini harus tidak seperti itu. Kami hanya komitmen bahwa yang harus kita perjuangkan bahwa masyarakat punya tanah punya bangunan maka dia harus punya tanah dan bangunan kembali. Terlepas apakah dia punya sertfikat atau IMB dan sebagainya...”.“...akirnya Minarak tidak mempermasalahkan bukti kepemilikan, sertifikat, petok D, letter $\mathrm{C}$ itu diiyakan. Asalkan dengan jaminan kalau petok D itu ada tandatangan camat dan Bupati. Itu kan solusinya. Jadi petok D, letter C dan sertifikat sudah sama hukumnya, itu hasil koordinasi pak SBY dan Minarak waktu itu...” (Kutipan wawancara dengan KH).
\end{abstract}

Keempat; proses negosiasi kolektif terkait skema (model) jual-beli. Munculnya payung hukum berupa Peraturan Presiden yang mengatur skema ganti rugi aset tanah dan bangunan milik korban bencana Lumpur Lapindo melalui mekanisme jual beli dengan cara pembayaran dicicil memunculkan respons yang beragam dari korban bencana Lumpur Lapindo. Dalam Perpres diatur tentang mekanisme pembayaran jual beli melalui dua tahap pembayaran, yakni tahap 1 pembayaran uang muka sebesar $20 \%$ yang dibayarkan secara kontan, dan tahap 2 pembayaran sebesar $80 \%$ yang dibayar secara diangsur (dicicil) untuk jangka waktu 2 tahun. Selama proses pembayaran cicilan, kepada korban bencana Lumpur Lapindo diberikan dana kompensasi berupa: (1) biaya pindah (evakuasi) sebesar Rp. 500 Ribu setiap KK; (2) jatah hidup (uang lauk-pauk) sebesar Rp. 300 Ribu untuk setiap jiwa selama 6 bulan; dan (3) biaya kontrak rumah sebesar Rp. 5 Juta untuk dua tahun.

Ketika korban bencana Lumpur Lapindo melakukan negosiasi kolektif terkait tuntutan tiga hal, yakni tentang tuntutan besaran nilai ganti rugi, tuntutan bukti kepemilikan aset, dan tuntutan tentang payung hukum, seluruh korban bencana Lumpur Lapindo memiliki sikap dan suara yang sama, mereka bersatu. Namun ketika pemerintah mengatur mekanisme pembayaran jual-beli dengan skema $20 \%$ dan $80 \%$, maka sikap dan suara korban bencana Lumpur Lapindo terpecah menjadi Empat kelompok. Ke-Empat kelompok tersebut meliputi: (1) Kelompok Gabungan Korban Lumpur Lapindo (GKLL) yang menuntut skema Cash and Carry $(\mathrm{CnC})$; (2) Kelompok Paguyuban Warga Renokenongo Menolak Kontrak (Pagarekontrak) yang menuntut skema Cash and Resettlement $(\mathrm{CnR})$; (3) Kelompok Gerakan Pendukung Perpres (Gepres) yang menyetujui keputusan pemerintah dengan pembayaran ganti rugi melalui skema 20\% dan 80\% (Cash dan Cicilan); dan (4) Kelompok 
Tim-16 yang menuntut skema Resettlement. Meskipun pemerintah mengeluarkan kebijakan yang menetapkan mekanisme pembayaran jual-beli melalui skema 20\% dan 80\% (Cash dan Cicilan), namun pihak PT. LBI tidak mampu menolak tuntutan korban bencana Lumpur Lapindo yang mengajukan tuntutan di luar skema ini. Akhirnya pihak PT. LBI menyetujui mekanisme pembayaran jual-beli melalui Tiga skema, yakni Cash and Resettlement (CnR), Cash dan Cicilan (skema 20\% dan 80\%), dan kelompok Resettlement.

\section{Simpulan}

Pemerintah (negara) dan pihak PT. LBI (korporasi) melakukan tindakan dominatif dalam pengelolaan sumberdaya Migas di wilayah Kecamatan Porong, Kabupaten Sidoarjo, Jawa Timur, yang mengakibatkan munculnya kesengsaraan bagi korban bencana (masyarakat). Bentuk dominasi pemerintah (negara) dan korporasi (PT LBI) dalam arena peristiwa bencana Lumpur Lapindo, sebagai berikut: (1) Kebijakan pemerintah dalam memberikan ijin eksplorasi Migas di wilayah Kecamatan Porong, Kabupaten Sidoarjo melanggar penggunaan peruntukkan Rencana Tata Ruang Wilayah (RTRW); (2) Komisi Nasional Hak Asasi Manusia (Komnas HAM) menyatakan kasus bencana lumpur Lapindo yang terjadi di Kabupaten Sidoarjo, Jawa Timur, merupakan pelanggaran terhadap hak asasi manusia; (3) Masyarakat di sekitar Porong, khususnya masyarakat Desa Renokenongo, melihat adanya proses yang tidak transparan dalam proyek eksplorasi Migas yang dilakukan oleh PT LBI; (4) Bencana semburan Lumpur Lapindo di Sidoarjo menjadi arena produksi kemiskinan dan ketidakaberdayaan bagi warga yang ada di wilayah Kecamatan Porong, dan sekitarnya, yang menjadi korban bencana Lumpur Lapindo; dan (5) Dominasi pemerintah atas korban bencana Lumpur Lapindo tercermin juga dalam kebijakan pemerintah, yakni berupa Peraturan Presiden (Perpres), terkait penyelesaian permasalahan dampak bencana Lumpur Lapindo yang merugikan masyarakat korban bencana.

Dalam konteks bencana lumpur Lapindo, terdapat beberapa hal yang dirasakan oleh warga korban bencana sebagai bentuk ketidakadilan. Bentuk ketidakadilan yang dirasakan oleh wargakorban bencana Lumpur Lapindo bukan hanya terkait dengan persoalan ganti rugi atas aset tanah dan bangunan saja, melainkan lebih luas dari itu, yakni menyangkut berbagai dimensi. Bentuk-bentuk ketidakadilan yang dirasakan oleh korban bencana Lumpur Lapindo, meliputi: (1) Bentuk ketidakadilan yang dirasakan oleh warga korban Lumpur lapindo terkait dengan persoalan kontroversi tentang masalah perijinan pengeboran; (2) Ketidakadilan yang terkait dengan inkonsistensi pelaksanaan kebijakan penggunaan peruntukkan Tata Ruang; (3) Bentuk ketidakadilan yang dirasakan oleh warga korban lumpur lapindo yang terkait dengan faktor penyebab terjadinya semburan lumpur; (4) Bentuk ketidakadilan yang dirasakan oleh warga korban bencana Lumpur Lapindo terkait dengan penyebutan istilah. Warga masyarakat menyebutnya dengan istilah bencana Lumpur Lapindo (Lula), sementara pihak pemerintah dan PT LBI menyebutnya dengan istilah bencana Lumpur Sidoarjo (Lusi); (5) Bentuk ketidakadilan yang dirasakan warga korban bencana Lumpur Lapindo di Sidoarjo, khususnya warga korban yang ada di sekitar pusat semburan Lumpur Lapindo, yang wilayahnya masuk ke dalam PAT, berkaitan dengan pembagian tanggungjawab proses pembayaran ganti rugi; (6) Bentuk ketidakadilan keenam yang dirasakan oleh warga korban bencana Lumpur Lapindo yang terkait dengan perlakuan terhadap warga yang terkena dampak semburan lumpur, yakni bahwa mereka menjadi masyarakat korban bencana alam; (7) Bentuk ketidakadilan yang dirasakan oleh warga korban lumpur lapindo yang terkait peran pemerintah yang lebih pro-kapitalis (pro-pengusaha) daripada pro-rakyat (warga korban); dan (8) Bentuk ketidakadilan yang dirasakan oleh warga korban bencana Lumpur Lapindo yang terkait dengan peran pihak PT. LBI dalam proses penyelesaian masalah dampak semburan lumpur, dimana pihak PT LBI menyatakan bahwa mereka tidak mempunyai kewajiban hukum untuk mengatasi dampak bencana Lumpur Lapindo. Melalui berbagai aksi kolektif, seperti aksi demonstrasi dan negosiasi, korban bencana Lumpur Lapindo menyampaikan beberapa tuntutan. Proses negosiasi kolektif yang dilakukan oleh korban bencana Lumpur Lapindo terhadap pihak pemerintah dan PT LBI, meliputi: (1) Negosiasi kolektif terkait besaran nilai ganti rugi; (2) Negosiasi kolektif terkait jaminan (payung) hukum bagi korban bencana Lumpur Lapindo; (3) Negosiasi kolektif terkait alat bukti kepemilikan aset; dan (4) Negosiasi kolektif terkait skema (model) jual-beli. 


\section{Daftar Pustaka}

Akbar AA (2012) Konspirasi SBY-Bakrie. Jakarta: INDOPETRO Publishing.

Babbie E (2008)The Belmont Basics of Social Research. USA: Thomson Wadsworth.

Creswell JW (2007) Qualitative Inquiry \& Research Design: Chhosing Among Five Approaches.

New Delhi: SAGE Publications.

Damsar (2010) Pengantar Sosiologi Politik. Jakarta: Prenada Media Group.

Denzin NK \& Lincoln YS (2009) Handbook of Qualitative Research (terj.). Yogyakarta: Pustaka Pelajar.

Febriasih HB (ed) (2009) Bisnis dan Demokrasi. Malang: Averroes Press.

Lovett FN (2001) Domination: A Preliminary Analysis. The Monist 84 (1): 98-112.

Marvasti AB (2004) Qualitative Research in Sociology: An Introduction. London: SAGE

Publications.

Neuman WL (2007)Basics of Social Research: Qualitative and Quantitative Appoaches. Boston: Pearson Education, Inc.

Patria N\& Arief A (1999) Anronio Gramsci: Negara \& Hegemoni. Yogyakarta: Pustaka Pelajar.

Perkins J (2007) Membongkar Kejahatan Jaringan Internasional (Terjemahan: Confessions of An Economic Hit Man). Jakarta: UFUK Press.

Rais MA (2008) Agenda Mendesak Bangsa: Selamatkan Indonesia. Yogyakarta: PPSK Press.

Scott JC (1990) Domination and the Arts of Resistance: Hidden Transcripts. New Haven and London: Yale University Press.

Sukmana O (2017) Pergulatan di Medan Lumpur: Potret Gerakan Sosial Korban Bencana Lumpur Lapindo dalam Melawan Dominasi Negara dan Korporasi. Malang: UMM Press.

Suka IG (2012) Dominasi Dalam Perspektif Teori Kritis. PUSTAKA, Jurnal Ilmu-Ilmu Budaya XII (1): 41-51.

Salim A (ed) (2001) Teori dan Paradigma Penelitan Sosial: Pemikiran Norman K. Denzin \& Egon Guba, dan penerapannya. Yogyakarta: Tiara Wacana.

Yin RK (2011) Qualitative Research from Start to Finish. New York: The Guilford Press. 